Vol. 1 No. 4 November 2021 e-ISSN : 2775-2593 | p-ISSN : 2775-2585

\title{
PENINGKATAN HASIL BELAJAR SISWA MATERI MAWARIS MELALUI PEMBELAJARAN CONTEXTUAL TEACHING AND LEARNING (CTL)
}

\author{
DWI ARI SETIAWATI \\ SMA Negeri 1 Purwanegara Banjarnegara \\ Email : biru.dwi@gmail.com
}

\begin{abstract}
ABSTRAK
Penelitian ini bertujuan untuk mengetahui peningkatan hasil belajar siswa setelah penggunaan model pembelajaran Contextual Teaching and Learning. Berdasarkan hasil belajar siswa pada tahun pelajaran sebelumnya terlihat rendahnya hasil belajar terutama pada materi Mawaris. Oleh karena itu penulis melakukan penelitian tindakan kelas dengan mengganti model pembelajaran yang tadinya menggunakan ceramah dan diskusi menjadi Pembelajaran Contextual Teaching and Learning. Pembelajaran CTL (Contextual Teaching and Learning) merupakan konsep pembelajaran yang menekankan pada keterkaitan antara materi pembelajaran dengan dunia kehidupan siswa secara nyata, sehingga siswa mampu menghubungkan dan menerapkan kompetensi hasil belajar dalam kehidupan sehari-hari. Penelitian ini menggunakan penelitian tindakan sebanyak dua siklus yang terdiri dari empat langkah yaitu: perencanaan, pelaksanaan, pengamatan dan refleksi. Subjek penelitian ini adalah siswa kelas XII.IPA.1 tahun pelajaran 2020/2021. Data diperoleh dari hasil tes formatif, lembar observasi kegiatan, dan lembar wawancara. Dari hasil analisis didapatkan bahwa hasil belajar materi mawaris mengalami peningkatan ketuntasan belajar dari 69,23\% pada siklus 1 menjadi $92,30 \%$ pada siklus 2 . Kesimpulan dari penelitian ini adalah bahwa pembelajaran Contextual Teaching and Learning dapat meningkatkan hasil belajar siswa.
\end{abstract}

Kata Kunci: Hasil Belajar, Mawaris, Contextual Teaching and Learning.

\section{ABSTRACT}

This study aims to determine the increase in student learning outcomes after using the Contextual Teaching and Learning learning model. Based on student learning outcomes in the previous school year, it was seen that the learning outcomes were low, especially on Mawaris material. Therefore, the authors conducted classroom action research by changing the learning model that previously used lectures and discussions into Contextual Teaching and Learning. CTL (Contextual Teaching and Learning) learning is a learning concept that emphasizes the relationship between learning materials and the real world of students' lives, so that students are able to connect and apply learning outcomes competencies in everyday life. This study uses two cycles of action research consisting of four steps, namely: planning, implementing, observing and reflecting. The subjects of this study were students of class XII.IPA.1 for the academic year 2020/2021. Data were obtained from formative test results, activity observation sheets, and interview sheets. From the results of the analysis, it was found that the learning outcomes of Mawaris material increased from $69.23 \%$ in cycle 1 to $92.30 \%$ in cycle 2 . The conclusion of this study is that Contextual Teaching and Learning learning can improve student learning outcomes.

Keywords: Learning Outcomes, Mawaris, Contextual Teaching and Learning.

\section{PENDAHULUAN}

Sejak awal, bidang ilmu pendidikan telah mengatasi berbagai tantangan dan perubahan dalam masyarakat. Kenyataan yang terjadi pada saat ini bahwa dunia terus berubah sehingga orang memerlukan pengetahuan dan keterampilan baru untuk mengelola kehidupan mereka sehari-hari (Lenher \& Wurzenberger, 2013). Perubahan terbaru dalam pendidikan menekankan perlunya untuk meningkatkan pengajaran yang mengarahkan siswa pada pemecahan masalah, komunikasi, keterampilan menalar, pengetahuan dan sikap, sebagai pengukuran hasil dari apa yang telah dipelajari oleh siswa (Nasrallah, 2014). Perubahan hasil belajar dapat diamati, 


\section{EDUCATIONAL : Jurnal Inovasi Pendidikan dan Pengajaran Vol. 1 No. 4 November 2021 e-ISSN : 2775-2593 | p-ISSN : 2775-2585}

dibuktikan, dan terukur dalam kemampuan atau prestasi yang dialami oleh siswa sebagai hasil dari pengalaman belajar (Nemeth \& Long, 2012) yang dibangun melalui proses pembelajaran (Singh, Srivastava, \& Singh, 2015).

Setiap proses pembelajaran tentunya diharapkan siswa memperoleh hasil belajar yang baik. Namun pada kenyataannya hasil belajar yang diperoleh siswa tidak selalu baik dan sesuai harapan. Sebagaimana yang menjadi standar baik atau tidaknya hasil belajar atas dasar KKM yang telah ditetapkan sebagai patokan keberhasilan proses pembelajaran. Hal ini harus menjadi perhatian dan bahan evaluasi dalam proses pembelajaran. Oleh karena itu strategi pembelajaran diperlukan guna meningkatkan kualitas pembelajaran. Strategi pembelajaran adalah cara-cara yang akan dipilih dan digunakan oleh seorang pengajar untuk menyampaikan materi pembelajaran sehingga akan memudahkan siswa menerima dan memahami materi pembelajaran, yang pada akhirnya tujuan pembelajaran dapat dikuasainya di akhir kegiatan belajar. (Hamzah B. Uno, 2008).

Dalam tataran empiris, tidak sedikit guru pendidikan agama Islam yang masih terpaku kepada strategi yang berorientasi konvensional dan monoton. Orientasi konvensional maksudnya guru membiarkan siswa menggantungkan diri pada kelompok/teman yang homogen, penekanan pada tugas dan sebagainya. Monoton maksudnya metode yang diterapkan satu macam, sistem pembelajaran satu arah misalnya dengan metode ceramah. (Kunandar, 2007)

Hasil belajar siswa yang belum baik menjadi salah satu permasalahan dalam pendidikan. Hasil belajar siswa menunjukkan kemampuan dan kualitas siswa sebagai dampak dari proses pembelajaran yang telah dilaluinya. Melton menyiratkan bahwa hasil belajar merupakan tindakan dan pertunjukan yang mengandung dan mencerminkan kompetensi siswa yang berhasil menggunakan konten, informasi, ide-ide dan alat-alat dalam pembelajaran. Oleh karena itu hasil belajar dapat didefenisikan sebagai kompetensi dan keterampilan yang dimiliki siswa setelah masa pembelajaran (Molstad \& Karseth, 2016).

Berdasarkan data nilai atau hasil belajar siswa kelas XII semester dua tahun pelajaran 2019/2020 pada mata pelajaran pendidikan agama Islam terdapat $64 \%$ yang memperoleh nilai sama atau di atas nilai standar minimal (75). Dan khusus pada materi (mawaris), siswa yang memperoleh nilai ulangan harian 75 ke atas hanya $53 \%$. Bagi sebagian siswa yang tidak memiliki kesadaran, pelajaran agama Islam adalah pelajaran yang membosankan, membahas keakhiratan saja. Padahal materi pembelajaran agama Islam sangat dekat dengan kehidupan sehari-hari, seperti materi mawaris. Materi ini sangatlah penting untuk dikuasai siswa, akan tetapi materi ini sering dianggap sulit oleh anak2, karena tidak hanya pemahaman terkait ahli waris dan bagiannya masing-masing harus dipahami, tapi juga cara menghitung waris yang memerlukan pengetahuan matematis membuatnya semakin sulit. Sehingga banyak anak-anak yang menyerah saat mempelajarinya.

Melihat hasil belajar siswa yang belum optimal, terutama pada materi Mawaris. Pertanyaan yang timbul dari permasalahan tersebut adalah mengapa hasil belajar siswa belum optimal. Merujuk pada perspektif teori belajar bahwasannya banyak faktor yang mempengaruhi hasil belajar siswa, baik secara internal maupun eksternal. faktor internal antara lain: motivasi belajar, intelegensi, kebiasaan dan rasa percaya diri. Faktor eksternal guru sebagai pembina kegiatan belajar, strategi pembelajaran, sarana dan prasarana, kurikulum dan lingkungan. Pembelajaran harus berpusat pada siswa (focus on learners), memberikan pembelajaran dan pengalaman belajar yang relevan dan kontekstual dalam kehidupan nyata (provide relevant and contextualized subject matter) dan mengembangkan mental yang kaya dan kuat pada siswa.

Di dalam model pembelajaran terdapat pengembangan desain instruksional yaitu proses untuk menentukan model pembelajaran apa yang paling baik dilaksanakan agar timbul perubahan pengetahuan dan keterampilan pada diri siswa. Salah satu pembelajaran yang mampu mengkondisikan sifat kemandirian siswa dalam proses belajar adalah melalui model Konstruktivitas. (Wina Sanjaya, 2008) Pembelajaran model Konstruktivitas ini membantu siswa untuk memperoleh informasi, ide, keterampilan cara berpikir dan mengekspresikan ide 
itu sendiri. Selain itu guru juga mengajarkan bagaimana siswa belajar. Salah satu alternatif model konstruktif yang mampu mengkondisikan sifat kemandirian siswa dalam proses belajar adalah melalui penerapan pembelajaran Contextual.

Berdasarkan hal tersebut penelitian ini mengambil salah satu faktor dalam peningkatan hasil belajar, yaitu faktor eksternal dari guru dengan penggunaan model pembelajaran contextual teaching and learning untuk meningkatkan hasil belajar siswa materi Mawaris kelas XII.IPA.1 SMA Negeri 1 Purwanegara Banjarnegara Tahun Pelajaran 2020/2021.

\section{METODE PENELITIAN}

Prosedur penelitian yang digunakan dalam penelitian ini adalah penelitian tindakan kelas. Rancangan yang digunakan adalah model rancangan yang diadaptasi Stephen Kemmis dan Mc. Taggart (1998) dengan menggunakan dua siklus, dengan masing-masing siklus terdiri dari empat tahapan yaitu: (1) perencanaan, (2) tindakan, (3) observasi dan evaluasi, dan (4) refleksi.

Menurut Arikunto (2008), terdapat empat langkah dalam model penelitian tindakan kelas yang dinyatakan dalam bentuk siklus sebagaimana ditunjukkan dalam diagram berikut:

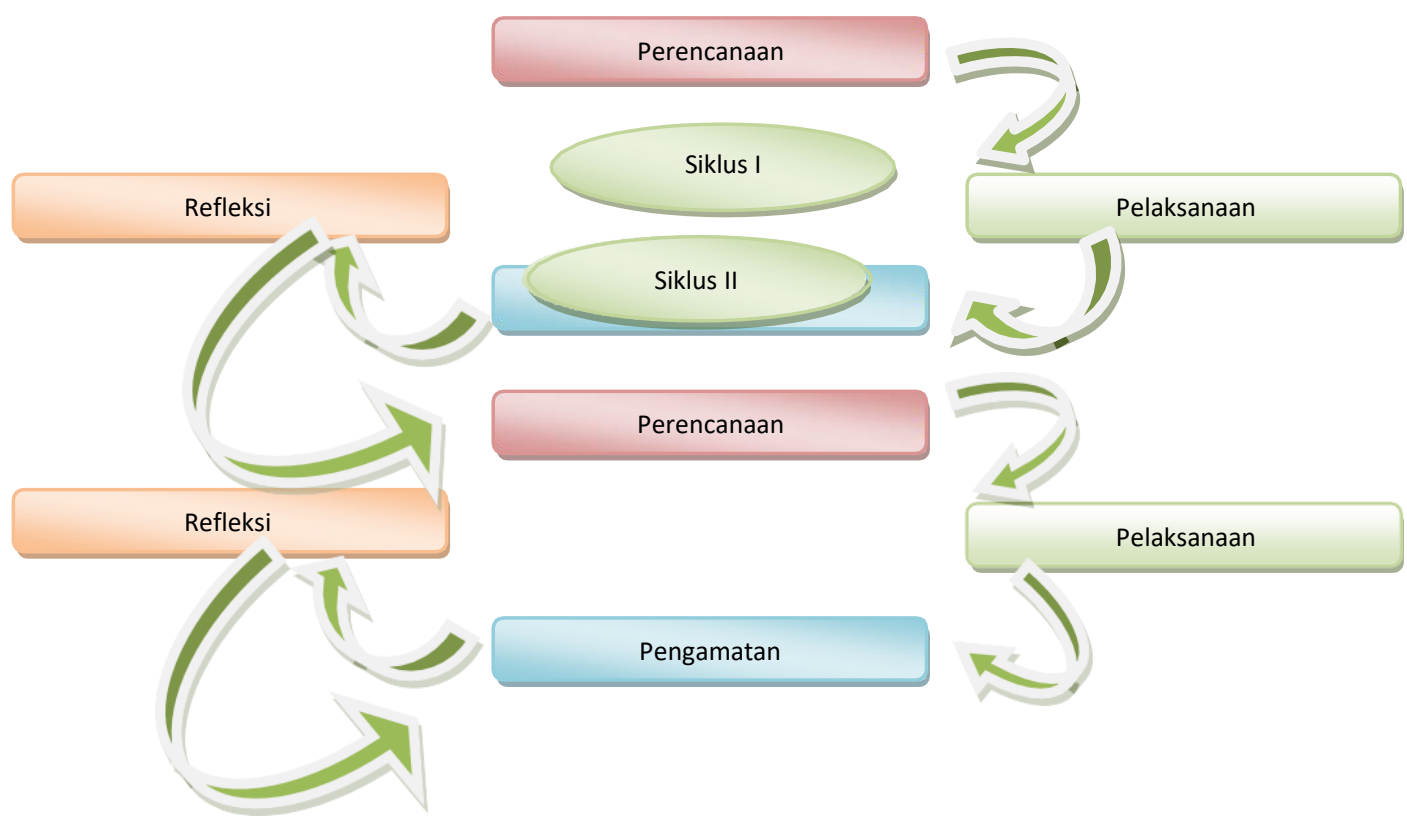

Gambar 1. Model Siklus Penelitian Tindakan Kelas

Pada siklus pertama (siklus I) sesuai dengan skema yang telah ditetapkan dilakukan beberapa tahapan: tahap (1) Perencanaan. Pada tahap ini peneliti membuat RPP dengan memasukkan kegiatan pembelajaran (tatap muka, tugas individu dan tugas kelompok), berkonsultasi dengan sesama guru Agama lain untuk membuat instrumen. Rancangan dilakukan bersama antara peneliti yang akan melakukan tindakan dengan guru lain yang akan mengamati proses jalannya tindakan. Tahap (2) Tahap Pelaksanaan tindakan dilakukan dengan pembelajaran di kelas. Pada tahap ini guru peneliti giat melakukan tindakan menggunakan metode CTL (Contextual Teaching and Learning). Rancangan tindakan tersebut sebelumnya telah dilatih untuk dapat diterapkan di dalam kelas sesuai dengan skenarionya. Skenario dari tindakan diupayakan dilaksanakan dengan baik dan wajar. Tahap (3) Tahap ini sebenarnya berjalan bersamaan dengan saat pelaksanaan. Pengamatan dilakukan pada waktu tindakan sedang berjalan, jadi, keduanya berlangsung dalam waktu yang sama. Pada tahap ini, guru yang bertindak sebagai peneliti melakukan pengamatan dan mencatat semua hal yang diperlukan dan terjadi selama pelaksanaan tindakan berlangsung. Pengumpulan data ini dilakukan dengan 
menggunakan belajar yang telah tersusun, termasuk juga pengamatan secara cermat terkait pelaksanaan skenario tindakan dari waktu ke waktu serta dampaknya terhadap proses dan hasil belajar siswa, dan (4) Tahapan ini dimaksudkan untuk mengkaji secara menyeluruh tindakan yang telah dilakukan, berdasarkan data yang telah terkumpul, kemudian dilakukan evaluasi guna menyempurnakan tindakan berikutnya. Refleksi dalam PTK mencakup analisis, sintesis, dan penilaian terhadap hasil pengamatan atas tindakan yang dilakukan. Jika terdapat masalah dari proses refleksi maka dilakukan proses pengkajian ulang melalui siklus berikutnya yang meliputi kegiatan: perencanaan ulang, tindakan ulang, dan pengamatan ulang sehingga permasalahan dapat teratasi.

Pada pelaksanaan siklus kedua (siklus II) proses pembelajaran yang dilakukan pada siklus ini meliputi: tahap (1) membuat RPP, berkonsultasi dengan sesama guru Agama guna membuat instrumen. Pada tahap menyusun rancangan diupayakan merupakan rancangan yang dibuat berdasarkan hasil perbaikan dari kelemahan pada siklus 1, tahap (2) melakukan tindakan berupa dilakukan dengan pembelajaran di kelas. Pada tahap ini guru peneliti giat melakukan tindakan menggunakan metode $C T L$, (3) melakukan pengamatan guna mengobservasi aktivitas belajar siswa selama proses pembelajaran, mengevaluasi proses pembelajaran. Yang terakhir adalah tahap (4) yaitu melakukan refleksi tentang hasil aktivitas belajar siswa selama proses pembelajaran dan post tes (tes hasil belajar) pada akhir siklus.

\section{HASIL DAN PEMBAHASAN}

\section{a. Hasil Penelitian}

\section{Siklus I pertemuan pertama}

Pelaksanaan siklus I dilaksanakan pada hari Selasa 04 Februari 2020. Guru masuk kelas pukul 07.00 WIB bersama observer. Kegiatan pembelajaran diawali dengan mengucapkan salam, tadarus, hafalan asmaul husna dan mengecek kehadiran siswa. Setelah itu guru menyampaikan materi yang akan disampaikan dengan memberikan apersepsi tentang materi Mawaris dengan menceritakan kasus pembagian mawaris yang ada di lingkungan sekitar tempat tinggal guru untuk memotivasi siswa dan menjelaskan tujuan serta indikator dari pembelajaran tersebut dengan menuliskan di papan tulis.

Kemudian kegiatan inti berlangsung selama 90 menit. Dalam kegiatan ini, guru menjelaskan mengenai pengertian mawaris serta jenis harta waris sebagai materi awal. Setelah itu guru melakukan apersepsi terhadap siswa dengan mengajukan pertanyaan mengenai siapa saja yang berhak menerima warisan dan bagaimana cara membagi waris yang diketahui siswa, dan guru memberi tanggapan terhadap jawaban siswa. Kemudian guru membagi siswa menjadi 5 kelompok dan memberikan LKS berisi soal pembagian waris dan didiskusikan bersama kelompok masing-masing. Pada kegiatan penutup, guru bersama siswa menyimpulkan hasil pembelajaran. Kemudian guru menyampaikan materi untuk pertemuan selanjutnya dan mengingatkan kembali kepada siswa untuk mempelajari materi yang telah dipelajari. Diakhir pembelajaran guru mengucapkan salam.

\section{Siklus I pertemuan kedua}

Pelaksanaan kedua dilaksanakan pada hari Selasa, 11 Februari 2020. Guru melakukan pendahuluan dengan memberi salam, hafalan asmaul husna dan mengecek keadaan siswa. Kemudian guru memberikan apersepsi mengenai pembelajaran sebelumnya yang bertujuan untuk mengembalikan ingatan siswa dengan mengajukan beberapa pertanyaan seperti apa itu mawaris? Dan bagaimana cara membagi waris? siswa dengan antusias menanggapi pertanyaan tersebut. Guru meminta anak berkelompok sesuai dengan kelompoknya pada pertemuan pertama kemudian menyelesaikan soal di Lembar Kerja Siswa mengenai pembagian harta waris kemudian dipresentasikan. Pada kegiatan inti berlangsung selama 90 menit dengan melakukan pendekatan diskusi. Pada siklus I pertemuan kedua guru menjelaskan cara mudah menentukan ahli waris dan cara menghitung bagian masing-masing ahli waris tersebut. Sebelum pembelajaran berakhir diadakan post test untuk mengukur pemahaman siswa terhadap materi yang telah dijelaskan. Berdasarkan 


\section{Vol. 1 No. 4 November 2021 e-ISSN : 2775-2593 | p-ISSN : 2775-2585}

hasil pengamatan /observasi dan hasil tes selama proses pembelajaran Siklus I dapat dilihat pada Tabel 1.

Tabel 1. Distribusi Nilai Hasil Belajar siswa Pada Siklus 1

\begin{tabular}{|c|l|c|}
\hline No. & \multicolumn{1}{|c|}{ Uraian } & Hasil Siklus 1 \\
\hline 1. & Nilai Tertinggi & 85,00 \\
2. & Nilai Terendah & 64,00 \\
3. & Nilai rata-rata tes hasil belajar & 74,68 \\
4. & Jumlah siswa yang tuntas belajar & 18 \\
5. & Jumlah siswa yang tidak tuntas & 8 \\
6. & Persentase ketuntasan belajar & $69,23 \%$ \\
\hline
\end{tabular}

Berdasarkan pada tabel 1 di atas, dapat diketahui bahwa hasil belajar siswa kelas XII.IPA.1 yang mengikuti pembelajaran dengan penerapan model CTL diperoleh nilai ratarata hasil belajar PAI materi waris sebesar 74,68 dan ketuntasan belajar 69,23\% atau ada 18 siswa dari 26 siswa sudah tuntas belajar. Hasil ini menunjukkan bahwa secara klasikal siswa belum tuntas belajar, karena siswa yang memperoleh nilai $\geq 75$ (KKM) hanya sebesar $69,23 \%$ lebih kecil dari prosentase ketuntasan yang dikehendaki yaitu sebesar $85 \%$.

Berdasarkan hasil refleksi siklus pertama (siklus I) diketahui bahwa tidak tercapainya ketuntasan aktivitas belajar siswa dipengaruhi oleh beberapa hal yaitu: 1) masih ditemukan beberapa penyelesaian yang kurang teliti, Hal ini diakibatkan guru kurang menekankan pada siswa pada saat mendemonstrasikan cara menyelesaikan perhitungan. 2) masih terdapat siswa yang pasif mengikuti pembelajaran seperti kurangnya keinginan siswa untuk bertanya dan menjawab pertanyaan guru. Oleh karena itu peneliti merasa perlu melakukan perbaikan tindakan terhadap proses pembelajaran yang telah dilakukan pada siklus pertama (siklus I) dengan lebih mendekatkan diri kepada siswa, guru memberikan contoh penyelesaian pembagian waris kepada siswa yang merasa kesulitan dalam menghitung pembagian waris, di samping itu guru membantu siswa secara intensif terutama siswa yang pasif.

\section{Siklus II Pertemuan Pertama}

Siklus ini dilaksanakan pada hari Selasa, 18 Februari 2020. Pada siklus ini kegiatan pembelajaran hampir sama dengan siklus pembelajaran sebelumnya hanya bedanya kelompok menjadi semakin kecil dan menindaklanjuti kekurangan-kekurangan yang terdapat pada siklus sebelumnya. Pada pertemuan pertama siklus ini, model pembelajaran yang diterapkan mengacu pada RPP yang telah disusun, yakni menerapkan model pembelajaran CTL. Kegiatan inti berlangsung selama 90 menit dengan membentuk kelompok kecil berisi 2 sampai 3 siswa per kelompok kemudian siswa diminta memilih dari kelompok tersenut satu anak untuk dihitung warisan yang akan diterima jika orang tuanya meninggal kemudian mempresentasikan hasil penghitungan waris. Sebelum presentasi guru menjelaskan sedikit tentang bagian-bagian dari masing-masing ahli waris agar siswa bisa memahami presentasi yang akan ditampilkan. Setelah siswa mempresentasikan hasil penghitungan waris tersebut, guru memberikan umpan balik dengan mengajukan pertanyaan seputar presentasi tersebut, seperti menanyakan kembali dari mana hasil warisan yang ditemukan siswa dalam presentasi. Kemudian masing-masing kelompok mempresentasikan hasil diskusi ke depan kelas dan kelompok yang lain menanggapi serta guru memberikan reward kepada siswa yang menjawab dengan benar.

Pada kegiatan penutup, guru menanggapi hasil diskusi dari siswa dan memberi penguatan sekaligus menyimpulkan hasil pembelajaran mengenai cara menghitung pembagian harta waris. Diakhir pembelajaran guru mengucapkan salam penutup. 


\section{Siklus II Pertemuan Kedua}

Siklus ini dilaksanakan pada hari Selasa, 25 Februari 2020. Guru melaksanakan pembelajaran sesuai dengan RPP yang telah disepakati oleh guru pengampu pendidikan agama Islam yang lainnya. Guru masuk kelas dengan mengucapkan salam pembuka, tadarus dan mendata siswa dengan menanyakan kesiapan untuk melaksanakan proses pembelajaran. Setelah itu guru menyampaikan materi yang akan disampaikan dengan memberikan apersepsi tentang cara menghitung bagian waris dan menjelaskan tujuan serta indikator dari pembelajaran secara lisan.

Pada kegiatan inti berlangsung selama 90 menit dengan kembali membentuk kelompok kecil dan menayangkan contoh cara menghitung waris dengan kasus yang terjadi di masyarakat. Setelah mengamati penjelasan penghitungan waris tersebut, masing-masing kelompok diharapkan dapat menghitung warisan yang akan diterima di keluarga masingmasing sesuai dengan pembagian yang ditentukan dalam syariat Islam depan kelas. Pada akhir kegiatan pembelajaran, guru kembali memberikan tanggapan berupa reward maupun perbaikan-perbaikan yang ditujukan kepada siswa, serta memberikan penguatan. Post test diberikan 20 menit sebelum kegiatan pembelajaran berakhir guna mengukur pemahaman siswa terhadap materi yang telah diberikan. Setelah dilakukan tindakan berupa pembelajaran di siklus kedua (siklus II) maka diperoleh hasil observasi aktivitas dan hasil belajar pada siklus kedua (siklus II) seperti terlihat dalam tabel 2.

Tabel 2. Distribusi Nilai Hasil Belajar siswa Pada Siklus 2

\begin{tabular}{|c|l|c|}
\hline No. & \multicolumn{1}{|c|}{ Uraian } & Hasil Siklus 2 \\
\hline 1. & Nilai Tertinggi & 90,00 \\
2. & Nilai Terendah & 70,00 \\
3. & Nilai rata-rata tes hasil belajar & 80,07 \\
4. & Jumlah siswa yang tuntas belajar & 24 \\
5. & Jumlah siswa yang tidak tuntas & 2 \\
6. & Persentase ketuntasan belajar & $92,30 \%$ \\
\hline
\end{tabular}

Berdasarkan pada tabel 2 di atas, dapat diketahui bahwa hasil belajar siswa kelas XII.IPA.1 yang mengikuti pembelajaran dengan penerapan model pembelajaran CTL diperoleh nilai rata-rata hasil belajar PAI BP materi Mawaris sebesar 80,07 dan ketuntasan belajar $92,30 \%$ atau ada 24 siswa dari 26 siswa sudah tuntas belajar. Hasil ini menunjukkan bahwa secara klasikal siswa sudah tuntas belajar, dan sudah memenuhi syarat karena jumlah siswa yang telah mencapai nilai $\geq 75(\mathrm{KKM})$ sebanyak $92,30 \%$ dan berada diatas kriteria ketuntasan klasikal 85\%, maka penelitian ini berakhir di siklus kedua 2. Perbandingan hasil belajar siswa pada sikus 1 dengan siklus 2 ditunjukkan pada Tabel 3.

Tabel 3. Perbandingan hasil belajar siswa pada siklus 1 dan siklus 2

\begin{tabular}{|c|l|c|c|}
\hline No. & \multicolumn{1}{|c|}{ Uraian } & Hasil Siklus 1 & Hasil Siklus 2 \\
\hline 1. & Nilai Tertinggi & 85,00 & 90,00 \\
2. & Nilai Terendah & 64,00 & 70,00 \\
3. & Nilai rata-rata tes hasil belajar & 74,68 & 80,07 \\
4. & Jumlah siswa yang tuntas belajar & 18 & 24 \\
5. & Jumlah siswa yang tidak tuntas & 8 & 2 \\
6. & Persentase ketuntasan belajar & $69,23 \%$ & $92,30 \%$ \\
\hline
\end{tabular}

Berdasarkan pada tabel 3 di atas, dapat diketahui bahwa hasil belajar siswa kelas XII.IPA.1 yang mengikuti pembelajaran dengan penerapan model pembelajaran CTL mengalami peningkatan dari siklus I ke Siklus 2 sebesar 3,39\% dari rata-rata 76,68 pada siklus I menjadi 80,07 pada siklus II. 


\section{EDUCATIONAL : Jurnal Inovasi Pendidikan dan Pengajaran Vol. 1 No. 4 November 2021 e-ISSN : 2775-2593 | p-ISSN : 2775-2585}

\section{b. Pembahasan}

Setelah menganalisis kemampuan siswa dalam menyelesaikan tes akhir siklus, diperoleh rata-rata nilai siswa pada siklus I adalah 74,68 dengan jumlah siswa yang tuntas atau mencapai nilai 75,00 adalah 18 siswa atau 69,23\% dari 26 siswa. Berdasarkan pekerjaan siswa pada siklus I masih ditemukan beberapa penyelesaian yang kurang teliti, Hal ini diakibatkan guru kurang menekankan pada siswa pada saat mendemonstrasikan cara menyelesaikan perhitungan. Menanggapi hal ini maka guru mengungkapkan kembali kesalahan pengerjaan tersebut pada saat melakukan apersepsi di siklus II.

Pada siklus II diperoleh rata-rata nilai siswa 80,07 dengan persentase ketuntasan kelas adalah $92,30 \%$ atau banyak siswa yang tuntas mengerjakan soal adalah 24 siswa. Kesalahan yang paling banyak dilakukan oleh siswa dalam menyelesaikan tes siklus II adalah pada indikator pembelajaran menghitung pembahagian warisan yang berkaitan dengan Radd.

Seperti telah diketahui bersama bahwasannya mata pelajaran pendidikan Agama menitikberatkan pembelajaran pada aspek kognitif, afektif, dan psikomotor sebagai pedoman prilaku kehidupan sehari-hari siswa. Untuk penyelesaian kesulitan yang ada maka penggunaan metode ini dapat membantu siswa untuk berkreasi, bertindak aktif, bertukar pikiran, mengeluarkan pendapat, bertanya, berdiskusi, berargumentasi, bertukar informasi dan memecahkan masalah yang ada bersama dengan anggota kelompok diskusinya. Hal inilah yang membuat siswa berpikir lebih tajam, lebih kreatif dan kritis sehingga mampu untuk memecahkan masalah-masalah yang kompleks dan efek selanjutnya adalah para siswa akan dapat memahami dan meresapi mata pelajaran seni budaya lebih jauh. Kendala yang masih tersisa yang perlu dibahas adalah kemampuan memahami tata cara penghitungan waris yang dicapai pada siklus I ini belum memenuhi harapan sesuai dengan tuntutan KKM mata pelajaran Pendidikan Agama Islam dan Budi Pekerti di sekolah ini yaitu sebesar 75. Oleh karenanya upaya perbaikan lebih lanjut masih perlu diupayakan sehingga perlu dilakukan perencanaan yang lebih matang untuk siklus selanjutnya.

Hasil yang diperoleh dari kemampuan memahami cara menghitung waris di siklus II menunjukkan bahwa kemampuan siswa dalam mengikuti pelajaran sudah cukup baik. Ini terbukti dari rata-rata nilai siswa mencapai 80,07 dengan ketuntasan belajar 92,30\%. Hasil ini menunjukkan bahwa model CTL telah berhasil meningkatkan kemampuan siswa menempa ilmu sesuai harapan. CTL merupakan model yang cocok apabila guru menginginkan mereka memiliki kemampuan berkreasi, berargumentasi, mengeluarkan pendapat secara lugas, bertukar pikiran, berargumentasi, mengingat penggunaan metode ini adalah untuk memupuk kemampuan intelektual, mendorong siswa untuk mampu menemukan sendiri, menempatkan diri pada posisi sentral dan mengupayakan agar siswa tidak belajar dengan menghafal. Dari hasil penelitian menunjukkan adanya peningkatan hasil nilai siklus I dan nilai siklus II, yaitu dari rata-rata nilai di siklus I adalah74,68 naik di siklus II menjadi 80,07. Untuk ketuntasan belajar juga mengalami kenaikan dari $69,23 \%$ pada siklus I menjadi $92,30 \%$ pada siklus II. Hal ini sejalan pula dengan temuan-temuan peneliti lain seperti yang dilakukan oleh Inten (2004) dan Puger (2004) yang pada dasarnya menyatakan bahwa metode pembelajaran yang diterapkan berpengaruh terhadap hasil belajar siswa. Dengan demikian dapat dikatakan penerapan model pembelajaran CTL dapat meningkatkan hasil belajar dan memahami Cara penghitungan harta waris. Pembelajaran model CTL sangat membantu guru meningkatkan kualitas pembelajaran di kelas terutama dalam mengajarkan materi memahami keunikan gerak tari kreasi maupun materi lainnya.

\section{KESIMPULAN}

Sesuai hasil penelitian dan pembahasan, maka dapat dikemukakan bahwa setelah dilakukan tindakan dengan menggunakan penerapan model CTL pada siswa kelas XII.IPA.1 SMA Negeri 1 Purwanegara semester genap tahun pelajaran 2020/2021 terjadi perubahan penguasaan materi penghitungan waris. Perubahan ini nampak pada hasil observasi maupun pos test yang didapat dari pre tindakan, tindakan pada siklus I, dan tindakan dari siklus II. Data 


\section{Vol. 1 No. 4 November 2021 e-ISSN : 2775-2593 | p-ISSN : 2775-2585}

perkembangan hasil peningkatan hasil belajar siswa dapat dilihat dari rata-rata perolehan nilai siswa pada masing-masing siklus mengalami peningkatan yakni pada siklus 1 rata-rata hasil belajar 74,68 pada siklus 1 menjadi 80,07 pada siklus 2 . Persentase ketuntasan belajar juga mengalami peningkatan dari $69,23 \%$ pada siklus 1 menjadi $92,30 \%$ pada siklus 2 . Dengan hasil penelitian ini, penulis menyarankan kiranya rekan-rekan guru yang lain dapat mencoba menerapkan model pembelajaran CTL pada materi lain yang lebih kompleks.

\section{DAFTAR PUSTAKA}

Arikunto, S. (2008). Penelitian Tindakan Kelas. Jakarta: Bumi Aksara. 16

Kunandar, (2007). Guru Profesional: Implementasi Kurikulum Tingkat Satuan Pendidikan (KTSP) dan Sukses Dalam Sertifikasi Guru. Jakarta: PT. Raja Grafindo Persada. 318319.

Lenher, D., \& Wurzenberger, J. (2013). Global Education - An Educational Perspective to Cope with Globalization? Campus-Wide Information System, 30 (5). 257-368.

Molstad, C. E., \& Karseth, B. (2016). National Curricula in Norway and Finland: The Role of Learning Outcomes. European Educational Research Journal, 15 (3). 329-344.

Nasrallah, R. (2014). Learning Outcomes' Rrole in Higher Education Teaching. Education, Business and Society: Contemporary Middle Eastern Issues, 7 (4). 257-276.

Nemeth \& Long. (2012). Journal of planning education and research 32 (4). 476-490

Puger, I Gusti Ngurah. (2004). Belajar Kooperatif. Diktat Perkuliahan Mahasiswa Unipas.

Sanjaya, Wina. (2008). Strategi Pembelajaran Berorientasi Standar Proses Pendidikan Jakarta: Kencana. 256

Singh, A. K., Srivastava, S., \& Singh, D. (2015). Student Engagement as The Predictor of Direct and Indirect Learning Outcomes in The Management Education Context. Metamorphosis, 14 (2). 20-29.

Uno, Hamzah. (2008). Model Pembelajaran Menciptakan Proses Belajar Mengajar Yang Kreatif Dan Efektif. Cet. 3. Jakarta: Bumi Aksara. 3 